\title{
UREA IN LAKE ERIE: ORGANIC NUTRIENT SOURCES AS POTENTIALLY IMPORTANT DRIVERS OF PHYTOPLANKTON BIOMASS
}

\section{B. Shafer Belisle ${ }^{\mathrm{a}, 1}$, Morgan M. Steffen ${ }^{\mathrm{a}, 2}$, Helena L. Pound ${ }^{\mathrm{a}, 3}$, Sue B. Watson ${ }^{\mathrm{b}}$, Jennifer M. DeBruyn $^{c}$, Richard A. Bourbonniere ${ }^{\mathrm{b}}$, Gregory L. Boyer ${ }^{\mathrm{d}}$ and Steven W. Wilhelm ${ }^{\mathrm{a}}$}

${ }^{a}$ Department of Microbiology, The University of Tennessee, Knoxville, TN 37996 USA

${ }^{\mathrm{b}}$ Aquatic Ecosystem Management Research Division, Science \& Technology Branch, Environment Canada, Burlington, ON L7R 4A6 Canada

${ }^{c}$ Biosystem Engineering and Soil Sciences, The University of Tennessee, Knoxville, TN, 37996 USA

${ }^{\mathrm{d}}$ Department of Chemistry, State University of New York, College of Environmental Science and Forestry, Syracuse, New York 13210, USA

* Corresponding author: email: wilhelm@utk.edu phone: 865-974-0665 FAX: 865-9744007

${ }^{1}$ Current address: Biosciences Division, Oak Ridge National Laboratory, 1 Bethel Valley Rd, Oak Ridge, TN 37831

${ }^{2}$ Current address: Department of Biology, James Madison University, Harrisonburg, VA 22807

${ }^{3}$ Current address: Grice Marine Lab, 205 Fort Johnson Rd., Charleston, SC 29412.

KEY WORDS: Microcystis, nitrogen, cyanobacterial blooms, Laurentian Great Lakes 


\begin{abstract}
Significant evidence shows that nitrogen $(\mathrm{N})$ supply may influence microbial community structure and, in some cases, the rate of primary productivity in fresh waters. To date, however, most focus has been on dissolved inorganic N (i.e., ammonia and nitrate), or dinitrogen gas. Far less is known about the effects of dissolved organic $\mathrm{N}$ such as urea on plankton activity, although this compound is both produced by in-lake processes and is a significant component of external loading. We evaluated the urea distribution and the activity of the major enzyme responsible for its assimilation (urease) in Lake Erie, which has a significant history of eutrophication. During 2012 and 2013, lake-wide surveys estimated surface urea concentrations and urease activity, along with phytoplankton composition and biomass, cyanobacterial toxins (microcystin), major nutrients and other physico-chemical parameters. In parallel, in situ 48-hour microcosm experiments were executed to test whether different chemical forms of dissolved $\mathrm{N}$ could stimulate phytoplankton biomass. Results confirmed urea was a bioavailable form of $\mathrm{N}$ with in situ urea turnover times ranging from hours (for summer, i.e., Aug 2012 and July 2013) to days (May 2013). Furthermore, we observed a positive correlation between urease activity and both microcystin concentrations and cyanobacterial dominance. Results also indicated a potential seasonal shift in the nutrient limiting phytoplankton biomass from phosphorus (P) to N. Our results reinforce the importance of both $\mathrm{N}$ and $\mathrm{P}$ in promoting phytoplankton growth and highlighted the need to consider organic nutrient sources as potentially important drivers of cyanobacterial blooms and toxin production.
\end{abstract}




\section{INTRODUCTION}

Phytoplankton blooms have become annual events in large freshwater systems, including Lake Erie and China's Lake Tai (or Taihu) (Qin et al., 2010; Rinta-Kanto et al., 2009b). The phytoplankton communities within these blooms consist of a diverse array of phototrophs, including diatoms, eukaryotic microalgae and cyanobacteria (Oliver et al., 2012). While phytoplankton are the base of the food web and drive processes and ecosystem services ranging from water quality to fisheries, large phytoplankton blooms are commonly referred to as harmful algal blooms (HABs) because they have a negative impact on human activities or the environment (Ho and Michalak, 2015; Zingone and Enevoldsen, 2000).

In the North American (Laurentian) Great Lakes, severe lake-wide blooms of diatoms and $\mathrm{N}$-fixing cyanobacteria and associated deterioration in water quality and hypolimnetic anoxia became so dire in the mid- to late-1960s that Lake Erie was described as "dead" by the popular press (Ashworth, 1986; Charlton, 1980). Nutrient (phosphorus, P) abatement efforts led to a short-lived (1980s through to the mid-1990s) recovery in the overall health of the lake, but by the mid-1990s a reemergence of cyanobacterial blooms dominated by different (relative to the 1960s), non-N-fixing cyanobacteria species began to occur in Lake Erie (Conroy et al., 2005). Recent biomolecular evidence suggests that Microcystis blooms in Lake Erie during August 2012 actively transported major nutrients (various $\mathrm{N}$ and/or P-containing compounds) as well as inorganic carbon (Steffen et al., 2015). The co-expression of $\mathrm{N}$ and $\mathrm{P}$ transporters by the cells was interpreted to mean that Microcystis spp. were actively scavenging both elements, which de facto implies that neither element was in excess. The expression of genes associated with inorganic carbon concentrating mechanisms was further suggestive of a limited availability of $\mathrm{CO}_{2}$ to this population (McGinn et al., 2003). This shift in phytoplankton community composition to cyanobacterial dominance can alter flow paths of energy and nutrients, reshaping the structure and trophic functionality of entire aquatic ecosystems (Oliver et al., 2012). This shift has also left researchers looking more closely at environmental drivers of community composition.

The observed historical transitions from a system dominated by $\mathrm{N}$-fixing cyanobacteria (Aphanizomenon flos-aquae and Anabaena spiroides) to a "recovered" Lake Erie and on now to one where Microcystis spp. is a more dominant component have been linked to changes in nutrient flux and chemistry (Steffen et al., 2014a). Changes in nutrient loading (specifically P- 
reductions) suggest a shift in conditions that determined the outcome of competition between cyanobacterial taxa, since the genetic richness (i.e., which species are present) of the cyanobacterial community has remained fairly constant over the last 40 years (Rinta-Kanto et al., 2009b). Of particular interest are members of the genus Microcystis, spherical cells that are irregularly grouped into colonies of various sizes and densities, which may have a stratified, colorless mucilage (Šejnohová and Maršálek, 2012). While some cyanobacteria, including Dolichospermum (syn. Anabaena), Aphanizomenon and Cylindrospermopsis, have the capacity to produce the enzyme nitrogenase to fix atmospheric nitrogen gas $\left(\mathrm{N}_{2}\right)$, Microcystis does not possess the complete set of genes required for this process (Frangeul et al., 2008; Kaneko et al., 2007; Steffen et al., 2014a) and must assimilate N from other sources.

Concurrent with the increasing dominance of Microcystis as a bloom-forming taxon in the mid-1990s (Brittain et al., 2000; Conroy et al., 2005), agricultural practices in North America have also experienced a major shift. Use of ammonium nitrate as the preferred $\mathrm{N}$-fertilizer in North America has waned in favor of urea-based fertilizers (USDA-ERS, 2013). Urea $\left(\mathrm{CO}\left(\mathrm{NH}_{2}\right)_{2}\right)$ currently accounts for more than $50 \%$ of the $\mathrm{N}$ used globally for agricultural fertilizer, constituting more than a 100-fold increase in the past 4 decades (Glibert et al., 2006). It is a preferred $\mathrm{N}$ source for agricultural fertilizer because of its solubility in water, low cost of application, and the minimal damage it causes to root crops. Urea leaving the land and entering the aquatic system has been shown to be assimilated as an $\mathrm{N}$ source by some cyanobacteria and phytoplankton in both freshwater and marine environments (Donald et al., 2011; Finlay et al., 2010; Solomon et al., 2010).

There are a variety of natural biological sources of urea in lakes, including phytoplankton, bacteria, zooplankton and fish (Bogard et al., 2012). Previous estimates suggest urea concentrations in aquatic ecosystems are consistently less than those of $\mathrm{NH}_{4}{ }^{+}$and $\mathrm{NO}_{3}{ }^{-}$, although urea may temporarily exceed these inorganic $\mathrm{N}$-sources for short periods or even for prolonged period when runoff from either non-point or sustained point inputs of $\mathrm{N}$ occurs (Glibert et al., 2014; Solomon et al., 2010). Indeed recent estimates from Lake Tai (Taihu) in China indicate urea concentrations were higher in riverine inputs than in open lake waters: an observation that suggests urea is rapidly consumed in aquatic systems (Glibert et al., 2014; Han et al., 2014). In total, contributions, studies have suggested urea may provide $10-50 \%$ of the bioavailable $\mathrm{N}$ in lake and river surface waters (Bogard et al., 2012; Wiegner et al., 2006). 
Despite the clear importance of urea in aquatic systems, no studies have evaluated its occurrence and few its potential for biological assimilation in Lake Erie (Chaffin and Bridgeman, 2014; Davis et al., 2015; Davis et al., 2010). The goal of this study was to address this knowledge gap. Most microorganisms use urease to assimilate urea; an enzyme that catalyzes the conversion of urea into carbon dioxide and ammonia. We therefore measured urease activity as a proxy for the ability of planktonic communities to assimilate this compound as an $\mathrm{N}$ source. We also investigated whether urea could act as an $\mathrm{N}$-source for Lake Erie phytoplankton over the growing season. Measurements of urease enzymatic activity, nutrient concentrations and phytoplankton biomass were made during three lake-wide surveys (August 2012, May 2013, July 2013). This work was complemented by in situ microcosm experiments, where lake water was amended with various $\mathrm{N}$ species (urea, nitrate, ammonium) to determine if different chemical forms of $\mathrm{N}$ influenced the accumulation of phytoplankton biomass in a manner consistent with other recent studies (Chaffin and Bridgeman, 2014; Chaffin et al., 2013; Finlay et al., 2010). Our results contribute to the growing body of work implicating urea as an important $\mathrm{N}$ source in large freshwater systems.

\section{METHODS AND MATERIALS}

\section{Environmental survey sample collection}

Water for field samples surveys and microcosm experiments were collected from Lake Erie during three cruises of opportunity that occurred in August 13-17, 2012, May 27-31, 2013, and July 22-26, 2013 aboard the CCGS Limnos. Surface water (1 meter depth) was collected from each station (21 different sites in total, although due to operational limitations, not all stations were visited on all trips) using 10-L Niskin sampling bottles and transferred to the ship's laboratory in 4-L acid-cleaned polycarbonate bottles. Prior to use, all polycarbonate bottles were soaked in $1 \% \mathrm{HCl}$ and rinsed thoroughly with Milli- ${ }^{\circledR}$ water (Millipore Corp., Billerica, MA, USA). Statistical relationships within the field data were determined using R version 3.02 (http://cran.r-project.org/). Principal components analysis was done using Primer v7.0.9 (PrimerE Ltd, Ivybridge, UK). Missing environmental data were estimated using an expectation maximum likelihood algorithm with 1000 iterations. Prior to PCA, variables were normalized 
(the mean was subtracted from each value and the resultant then divided by the standard deviation) to account for the fact that they are measured on different scales.

\section{Microcosm Experiments}

Nutrient enrichment experiments were conducted in microcosms maintained in on-deck incubators that simulated in situ water column conditions during three CCGS Limnos cruises. Microcosm experiments were performed at two ecologically relevant and historically well-

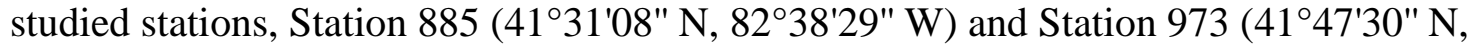
$83^{\circ} 20^{\prime} 00^{\prime \prime}$ W) (Figure 1). Station 885 was chosen because of the diversity of cyanobacteria historically present at this site, while Station 973 was chosen because of its proximity to the inflow of the Maumee River into Lake Erie, and a long history of Microcystis-dominated phytoplankton populations in the region (e.g., Rinta-Kanto et al., 2005; Rinta-Kanto et al., 2009b). Surface water (1 m) from each station was dispensed into acid-washed 1.2-L polycarbonate bottles and enriched with different nutrient amendments. Along with control (no nutrients added) treatments, a matrix of individual $\mathrm{N}$ additions ( $180 \mu \mathrm{M}$ final concentration added $\mathrm{N}$, from either ammonium, nitrate or urea (i.e., $90 \mu \mathrm{M}$ urea added)) or $\mathrm{P}$ (final concentration $1 \mu \mathrm{M}-\mathrm{PO}_{4}$, added from a mixture of $1: 4, \mathrm{KH}_{2} \mathrm{PO}_{4}: \mathrm{K}_{2} \mathrm{HPO}_{4}$ ) was deployed in triplicate. These concentrations were chosen to be consistent with those used in previous lab (Steffen et al., 2014b) and field (Davis et al., 2015) experiments, and provided non-limiting, but also non-toxic, concentrations of nutrients. Sealed bottles were incubated in the deck incubator for $48 \mathrm{~h}$ at $\sim 37 \%$ incident radiation (approximating light at $1 \mathrm{~m}$ in depth, DeBruyn et al., 2004; Wilhelm et al., 2003). Following incubation, aliquots from each microcosm treatment were removed and analyzed for chlorophyll a $(\operatorname{chl} a)$ concentrations as well as the microscopic enumeration of phytoplankton as described below.

\section{Biological parameters measured}

Chla concentrations were estimated using the non-acidification method (Welschmeyer, 1994), and served as a proxy for total phytoplankton biomass. For both surface waters and microcosms, $50 \mathrm{~mL}$ of water was filtered through $0.2-\mu \mathrm{m}$ nominal pore-size polycarbonate membrane filters (47 mm diam., Millipore) and stored in a $2.0 \mathrm{~mL}$ cryovials (Corning, NY) at $-20^{\circ} \mathrm{C}$ until analysis. Filters were extracted into $90 \%$ acetone overnight $(24 \mathrm{~h})$ at $-20^{\circ} \mathrm{C}$ and chlorophyll 
concentrations estimated fluorometrically (Turner Designs 10-AU; Sunnyvale, CA, USA). For in situ estimates of community structure, the percentage of chlorophyll assigned to phycocyanin (PC)-rich cyanobacterial species was estimated fluorometrically using a bbe-Moldaenke $\mathrm{GmbH}$ Algal Online Analyzer (AOA, aka FluoroProbe; Schwentinental, Germany) on board the ship and at the time of sample collection. Separate samples were collected from $1 \mathrm{~m}$ depth and triplicate $100 \mathrm{ml}$ samples were sequentially passed through the AOA at the start of each incubation. Chlorophyll fluorescence was assigned to green algae, heterokonts (dinoflagellates + diatoms), phycoerythrin-rich algae and PC-rich algae. The percent chlorophyll contributed by PC-rich species was calculated by dividing the PC-rich algal channel by the total bbe-chlorophyll channel (Kring et al., 2014).

Dissolved nutrient analyses for total nitrogen (TDN), total dissolved Kjeldahl nitrogen (TdKN), total phosphorous (TDP), soluble reactive phosphorus (SRP), $\mathrm{NH}_{3}-\mathrm{N}$ (ammonia), $\mathrm{NO}_{3} / \mathrm{NO}_{2}-\mathrm{N}$ (nitrate/nitrite), and silicate $\left(\mathrm{SiO}_{2}\right)$ were performed on membrane-filtered $(0.45-\mu \mathrm{m})$ samples at the National Laboratory for Environmental Testing (Environment Canada) using their standard techniques (NLET, 1994). Urea concentrations were measured using the 'Direct Method': a colormetric assay based on the reaction of urea with diacetylmonoxime, as outlined by Revilla et al. (2005). Briefly, water samples were collected from each station and filtered through pre-combusted $25 \mathrm{~mm}$ Glass Fiber Filters (GF/F) (Kent, UK). Filtrate was stored at $-20^{\circ}$ $\mathrm{C}$ until analysis in a lab setting where they were measured in triplicate and analyzed using a BioMate 5 UV-Visible Spectrophotometer at $520 \mathrm{~nm}$ as previously described (Revilla et al., 2005). Standard curves were generated for each survey using a range of urea stock solutions $(0$, $0.5,2.0,5.0,7.5$, and $10.0 \mu \mathrm{M}$ ) with all concentrations expressed in molar $\mathrm{N}$ - equivalents. Environment Canada provided $\mathrm{pH}$ and surface temperature data for each station, at the time of sampling, from the ship's automated water column profiler.

Urease activity (maximal) was determined on ship by measuring the accumulation of $\mathrm{NH}_{4}{ }^{+}$, which is a product of urea metabolism. Surface water $(50 \mathrm{~mL})$ from each station was filtered through pre-combusted $\left(450^{\circ} \mathrm{C}\right.$ for $\left.4 \mathrm{~h}\right) 25-\mathrm{mm} \mathrm{GF} / \mathrm{F}$ glass fiber filters. Urease activity was measured using the indophenol method optimized for aquatic environmental samples (Solomon et al., 2007). Each sample was assayed at room temperature (the first hour after collection) in triplicate and analyzed using a BioMate 5 UV-Visible Spectrophotometer at 640 $\mathrm{nm}$. Calibration for each survey was performed using a range of freshly prepared $\mathrm{NH}_{4}{ }^{+}$stock 
solutions $(0,1.0,2.5,5.0,7.5$, and $10.0 \mu \mathrm{M})$. Due to the manner in which these data were collected, activity here should be considered substrate-saturated ( $20 \mu \mathrm{mol}$ urea was added as substrate for each enzyme reaction) and thus the maximum possible rate.

Total microcystin activity in water samples, expressed as microcystin-LR equivalents, was determined using the protein phosphatase inhibition assay (PPIA). Samples (20 L) were collected on GF/F filters for toxin extraction as in our previous work (Rinta-Kanto et al., 2009a). Filters were extracted with 50\% methanol using ultrasound, clarified by centrifugation and microcystins assayed in 96-well plates containing 0.1 milliunits enzyme (recombinant protein phosphatase 1A, catalytic subunit, Roche Applied Science), $1.05 \mathrm{mg}$ para-nitrophenyl phosphate (Sigma) and $10 \mu \mathrm{L}$ of sample or microcystin-LR (Sigma Biochemical) using the method of Carmichael and An (1999). The PPIA gives an integrated value for microcystin activity, and thus toxin concentrations are reported as microcystin-LR equivalents as other microcystin congeners were also likely present in these samples (Boyer, 2007).

Phytoplankton enumeration and identification in microcosm samples were performed on Lugol's Iodine preserved samples using microscopic morphometrics (Auinger et al., 2008; Wehr and Sheath, 2003). Samples (50 mL) were collected and preserved with $0.5 \mathrm{~mL}$ of Lugol's Iodine (100 $\mathrm{g} \mathrm{KI} \mathrm{L}^{-1}$ and $50 \mathrm{~g} \mathrm{I}_{2} \mathrm{~L}^{-1}$ ), and stored at $4^{\circ} \mathrm{C}$ (Auinger et al., 2008). Fixed samples were allowed to settle (3-5 min) in a $1 \mathrm{~mL}$ Sedgwick-Rafter counting slide then analyzed at 100 or 400 $\mathrm{x}$ magnification on a Micromaster light microscope (ThermoFisher). Each sample was analyzed by taking four horizontal transects, ten fields of view each, which encompassed the full height and width of the slide (Chorus and Bartram, 1999; Saxton et al., 2012). The resulting 40 randomly selected fields of view were digitally imaged and saved using Micron imaging software (Westover Scientific), for later identification using established taxonomic features (Guillard and Sieracki, 2005; Wehr and Sheath, 2003). Organisms observed for each sample were identified and counted from the 40 randomly selected fields of view. Differences in cell abundance were determined using Tukey's HSD comparison of means, with significance considered at $\mathrm{p} \leq 0.1$.

\section{RESULTS}

\section{Field surveys}


Sites were surveyed on cruises during August 2012, May 2013, and July 2013 with collection across all three basins of Lake Erie at 21 individual stations (Figure 1). Extractable chlorophyll $a$ (chla) concentrations (a proxy for phytoplankton biomass) for August 2012, May 2013 and July 2013 ranged from 1.6 to $25.4 \mu \mathrm{g} \mathrm{L}^{-1}, 0.7$ to $37.4 \mu \mathrm{g} \mathrm{L}{ }^{-1}$, and 1.0 to $72.5 \mu \mathrm{g} \mathrm{L} \mathrm{L}^{-1}$ respectively (Table 1). Station 1163 exhibited the highest chl $a$ concentration in May 2013 and July 2013 while for August 2012 Station 973 had higher biomass as estimated from chla. The contribution of the cyanobacteria to the total chlorophyll was higher in July and August ( 21\%) than in the May samples ( 8\%), but varied across stations. Station 1163 had abundant cyanobacteria throughout the season, whereas station 973 showed a seasonal increase in the proportion of the population that was cyanobacterial $(0 \%, 21 \%$ and $79 \%$ for the samples collected in May, July and August, respectively).

Nutrients (TDN, TDP and SRP) for Aug 2012 ranged from 1.5 to $11.6 \mu \mathrm{M}, 0.13$ to 4.94

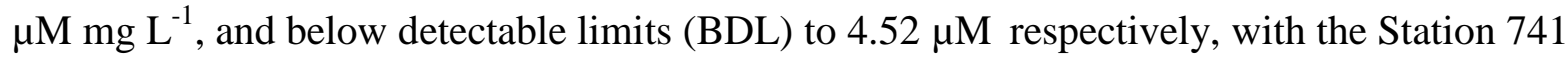
(closest to the Maumee River inflow) exhibiting the highest measurements for all three (Electronic Supplementary Material (ESM) Table S1). Similarly, July 2013 concentrations for TDN, TDP, and SRP were highest at Station 741 and ranged from 2.49 to $26.6 \mu \mathrm{M}, 1.55$ to 4.97, and BDL to $2.67 \mu \mathrm{M}$ (respectively). May 2013 station measurements for SRP ranged from BDL to $0.64 \mu \mathrm{M}$ (TDN and TDP data were not collected).

Urea concentrations across the three cruises ranged widely, exceeding $6 \mu \mathrm{M}$ (i.e., $\sim 0.2 \mu \mathrm{g}$ urea- $\mathrm{N} \mathrm{L}^{-1}$ ) during observations in Aug 2012 (average $=2.08 \pm 1.56 \mu \mathrm{M}$ urea-N). Average concentrations were noticeably lower in May $2013(0.46 \pm 0.19 \mu \mathrm{M}$ urea-N) and July 2013 (1.47 $\pm 0.71 \mu \mathrm{M}$ urea-N) (Table 1), although this pattern largely reflected the low concentrations at 2 stations (741 and 1326). Higher average urease rates were observed during the May 2013 cruise $\left(1.25 \pm 0.43 \mu \mathrm{M}\right.$ urea- $\left.-\mathrm{N} \mathrm{h}^{-1}\right)$ relative to August $2012\left(0.16 \pm 0.17 \mu \mathrm{M}\right.$ urea- $\left.\mathrm{N} \mathrm{h}^{-1}\right)$ and July 2013 $\left(0.16 \pm 0.11 \mu \mathrm{M}\right.$ urea- $\left.\mathrm{N} \mathrm{h}^{-1}\right)($ ESM Figure S1A, Table 1).

The relationship between chl $a$ and urea concentrations was not significant when combining data from August 2012, May 2013, and July 2013 (ESM Figure S1), even after log transformation. There was, however, a significant (but weak) correlation between maximal urease activity and chl $a$ for the August 2012 cruise (Figure 2A, August 2012, p $=0.034, R^{2}=$ 0.282; Figure 2B, May 2013, $p=0.403, R^{2}=0.050$; Figure $2 C$, July 2013, $p=0.312, R^{2}=$ 0.093). 
Across all three surveys a series of statistical relationships emerged from our Spearman analyses (Figure 3, ESM Table S2). Significant correlations were observed between microcystin concentrations and urease $\left(r_{s}=0.47, \mathrm{p}<0.05\right)$ and the resulting relationship with urea turnover (hours, $r_{s}=-0.51, \mathrm{p}<0.05$ ). While there was a significant relationship between urease and $\mathrm{NH}_{3}$ estimates $\left(r_{s}=0.55, \mathrm{p}<0.05\right)$, all other relationships between urea or urease and nutrients were non-significant. Microcystin concentrations were significally related $(\mathrm{p}<0.05)$ to both TdKN $\left(r_{s}\right.$ $=0.66)$ and TDP $\left(r_{s}=0.44\right)$.

Combining all these data, a principle component analysis revealed that stations generally clustered according to sampling dates, with May 2013 stations clustering away from August 2012 and July 2013 (Figure 4). Urease activity and temperature emerged as important discriminators between these dates, with highest urease activity seen in conjunction with the lowest temperatures. Indeed, overall there was a strong inverse relationship $\left(r_{s}=-0.49, p<0.05\right)$ between temperature and urease activity (ESM Figure S2, ESM Table S2). It should be noted that two of the stations that appeared as outliers on the PCA plot included samples collected within the warm and shallow Sandusky Bay (station 1163) and Maumee Bay (741) (Figure 4). The third (station 1326) is off the coast of Cleveland $(\mathrm{OH})$ and potentially influenced by the regional urban environment.

\section{Microcosm Experiments}

Nutrient amendment experiments were conducted at stations 973 and 885 during August 2012, May 2013, and July 2013. August 2012 samples showed no significant difference between the non-amended control treatment and the phosphorus amendment for either station (Figure 5AB). The addition of nitrogen $(180 \mu \mathrm{M}-\mathrm{N})$, however, significantly stimulated chla concentrations across all $\mathrm{N}$ treatments compared to the control treatment at both stations (Figure 5A-B).

Chlorophyll biomass within the experimental bottles for May 2013 was not significantly different from the controls for all treatments at both stations (Figure 5C-D). Biomass accumulation for July 2013 experiments was statistically similar to respective controls for all treatments at station 973 (Figure 5E). The same was true for station 885, with the exception of the $\mathrm{P}$ treatment (Figure 5F).

Given our interest in the influence of nitrogen on the phytoplankton community composition in this system, we investigated the densities of several cyanobacterial populations in 
August 2012 microcosms. For both stations 885 and 973, Microcystis cell densities were statistically similar to the respective controls for all treatments (ESM Figure S3 A-B, E-F). Similar results were observed for Dolichospermum cell counts for Station 885 (ESM Figure S3 B) and Station 973 (ESM Figure S3 F), with the $\mathrm{NO}_{3}-\mathrm{N}$ treatments being the only treatments that were statistically different from the control. It should be noted that Planktothrix and Cylindrospermopsis/Raphidiopsis were only observed at station 885, but that both increased in the ammonium treatment.

\section{DISCUSSION}

The proliferation of blooms of potentially toxic cyanobacteria over the past 20 years has led to a re-evaluation of our efforts to constrain bloom occurrence via nutrient management. Our observations indicate that the accumulation of biomass in phototrophs can be limited at different locations and different times of the year by the concentration of either $\mathrm{N}$ or P-substrates. Urea is an important $\mathrm{N}$-containing substrate, and its potential contribution as a $\mathrm{N}$-source at different times in the growing season can be described by estimates of urea concentration and the activity of the enzyme (urease) responsible for its consumption.

Solomon et al., (2010) reported that not all phytoplankton possess the same ability to use urea as a source of nitrogen, and some even lack enzymes for the uptake and/or catabolism of urea. It is well-documented, however, that cyanobacteria such as Microcystis spp. (McLachlan and Gorham, 1962) as well as Anabaena spp. (Mackerras and Smith, 1986) have the capability to use urea as a nitrogen source. This ability to use urea potentially contributes to the success of some bloom-forming cyanobacterial species, such as M. aeruginosa (Han et al., 2014; Huang et al., 2014). Multiple field studies have provided evidence to support this idea in freshwater systems around North America (Davis et al., 2010; Donald et al., 2011; Finlay et al., 2010), and recent observations have documented the activity of urea acquisition and metabolism genes in water samples collected concurrent with our current observations (Steffen et al., 2015). In this study, we build on this previous genetic evidence through direct measurements of the presence and metabolism of urea across Lake Erie as well as its influence on phytoplankton biomass in the eutrophic western basin and Sandusky sub-basin of Lake Erie.

To gauge the potential for urea to play a role in lake function, its concentration in the lake as well as the capacity of the community (via an assay for enzyme activity) to process (i.e., 
assimilate) this compound was measured. As noted, August 2012 measurements of urease activity and chl $a$ concentration exhibited a direct statistical correlation (Figure 2). However, no significant statistical correlation was observed within the May and July 2013 samples or when these data were pooled (ESM Table S2). In previous field measurements of urease activity, researchers had difficulty in identifying which phytoplankton species contributed the largest percentage of community urease activity (Solomon, 2006), and this unfortunately remains the case here. In samples from the Kranji Reservoir (Singapore), Penn and colleagues (2014) attributed all of the potential urease gene activity to Microcystis. While we do not have the data to reproduce this observation, the positive relationship between urease activity and microcystin concentrations supports this observation (Figure 3B). However, the lack of a correlation between urease activity and chl $a$ in the current study supports the idea that non-photosynthetic members of the community (e.g., heterotrophic bacteria) may be contributors to the observed urease activity (vis a vis Collier et al., 2009). Results from other published field experiments in two locations found that measurements of urease activity decreased as chla increased (Solomon et al., 2007). While these relationships are important, they also suffer from several potentially confounding factors, including (1) a temporal disconnect, as use of urea must occur prior to the accumulation of biomass if it is acting as a $\mathrm{N}$ source stimulating growth of the bloom (i.e., the relationship we are seeing is not "cause" but "effect") and (2) biomass accumulation may stimulate internal urea cycling due to increased protein turnover: internal recycling (driven by new protein biosynthesis in bacteria) would mean that less nitrogen is available to enter the urea cycle.

Estimates of urea concentrations across Lake Erie follow an inverse relationship relative to measurements of urease activity (i.e., higher urease activity occurs at lower urea concentrations, ESM Figure S1A). Urea concentrations were lowest during sampling cruises conducted during the early summer months (May/June), and highest during warmer sampling cruises occurring in the late summer and fall months (July/August) resulting in a cross seasonal relationship with temperature that is significant $\left(r_{s}=0.71, \mathrm{p}<0.05\right.$; Table S2). Using this information, maximal urease activity rates in May $\left(0.66\right.$ to $\left.1.96 \mu \mathrm{M}-\mathrm{N} \mathrm{h}^{-1}\right)$ and in situ concentrations during that period imply turnover times for urea of $0.2-1.2 \mathrm{~h}$ during that period. In contrast, turnover times for pools of urea during July and August were longer (up to > $150 \mathrm{~h}$ ). Previously published reports have shown that higher temperatures during summer months can 
increase heterotrophic bacteria activity and result in increased urea production from purines, compared to other seasons (Berg and Jorgensen, 2006). While our measured concentrations of urea in Lake Erie are consistent with this pattern, we did not observe an increase in urease activity with the increase in water temperature (ESM Figure S2), strongly suggesting another level of regulation of urease activity (e.g., substrate or total $\mathrm{N}$ supply rates, changes in microbial community structure, the overall N-status of cells (e.g. Figure 5), etc.) is more important. This is in some ways surprising, as enzyme active generally shows a positive relationship with temperature, (Juan et al., 2010). However, this relationship between temperature and urease needs to be interpreted with some caution as we experienced relatively minor changes in water temperature within a given cruise $\left(2-5^{\circ}\right.$, Table 1$)$ and the changes in temperature between the spring and late summer cruises (as well as different locations) were also associated with changes in planktonic community structure that may have a much greater effect on this observation.

To test the potential for urea to be a nutrient (i.e., nitrogen) source for Lake Erie phytoplankton, we completed a series of microcosm assays designed to evaluate nutrient limitation of biomass production and the potential use of different $\mathrm{N}$ sources (Figure 5). During the August 2012 experiment, addition of $\mathrm{P}$ alone did not stimulate chl $a$ accumulation, while the addition of all $\mathrm{N}$ (nitrate, urea, and ammonia) sources resulted in statistically increased chla concentrations, suggesting the community was $\mathrm{N}$-limited and that phytoplankton were able to access all forms of $\mathrm{N}$ we provided. This observation further suggests that urea was as efficient as other $\mathrm{N}$ sources at stimulating primary producers. In contrast, neither the addition of $\mathrm{N}$ or $\mathrm{P}$ in May 2013 stimulated chla production, implying that other factors (temperature, light, virus-lysis or grazing) may limit primary producers at this time of year. The July 2013 experiments demonstrated biomass production was stimulated by added $\mathrm{P}$ but not added $\mathrm{N}$, consistent with findings from the previous decade (Wilhelm et al., 2003). These observations are in agreement with the seasonal shifts in nutrient-limitation seen in other large lakes such as Taihu (Xu et al., 2010). The results in our experiments and those of others (Chaffin et al., 2013; Davis et al., 2015) provide additional evidence for consideration of both $\mathrm{N}$ and $\mathrm{P}$ as important limiting nutrients, and that both $\mathrm{N}$ concentrations and seasonal effects need be considered for models aiming to predict late season bloom events (e.g., Microcystis).

To examine the August stimulation of chl $a$ by $\mathrm{N}$ addition further, we enumerated phytoplankton cells from samples collected during the August 2012 experiment. While all 
treatments amended with $\mathrm{N}$ demonstrated increased total chlorophyll concentrations, surprisingly the only increase in cell density was in treatments where ammonia was added; additionally, only the Planktothrix and Cylindrospermopsis / Raphidiopsis groups increased. Increased chla in the absence of increased cell density may be due to the short time course of the experiments: microcosm experiments with natural communities are by necessity kept short to reduce potential bottle effects (DeBruyn et al., 2004; Hare et al., 2005; Wilhelm et al., 2003). It is quite likely that we observed rapid physiological changes within the phytoplankton community (i.e., a rapid increase in chl $a$ as nutrient limitation is relieved) that outpaced the slower net growth rate of phytoplankton, making it difficult to detect any accumulation of new cells. To address this limitation, future microcosm experiments may benefit from a longer incubation period under in situ conditions, and the use of other metrics (e.g., $\mathrm{F}_{\mathrm{v}} / \mathrm{F}_{\mathrm{m}}$ - a standard metric of photosystem II stress, specific RNA/DNA ratios, etc) that could markedly augment such observational studies.

One other observation that arose from this study was the linkage between microcystin concentrations and various environmental parameters. Microcystin concentrations correlated positively with chla, the proportion of cyanobacteria, urease activity, and with both TdKN and TDP concentrations (ESM Table S2). The relationship between microcystin and N-cycling is of interest, as it builds upon observations from similar enrichment studies in Sandusky Bay (Davis et al., 2015). In addition, linkages between nitrogen-status of the cell and toxin production have been inferred through genetic regulatory mechanisms for toxin production (Neilan et al., 2013). To this end, not only does the present study add to the gathering wealth of data on N-loading and phytoplankton species succession and seasonal biomass in Lake Erie (Chaffin and Bridgeman, 2014; Chaffin et al., 2013), it also supports the general idea that nitrogenous chemical species need to be considered as potentially important drivers of cyanobacterial toxin production.

Overall our observations provide insight into the ambient concentrations of urea in Lake Erie, and the potential for the microbial community to hydrolyze this $\mathrm{N}$ source. We also add to other studies showing the markedly different effects of added nutrients on biomass (chlorophyll a) accumulation at different times of year. While much of the load of urea to the system is potentially from internal cycling (Bogard et al., 2012), the nearshore to offshore gradients we observed suggest there was significant contribution to in-lake levels from the catchment (although the long residence time of Lake Erie water relative to the rapid turnover time estimated for the enzyme activity suggest internal sources must also be active). The continued reduction of 
phosphorus loading into eutrophic systems remains an important focal point for future management practices; however, failure to address point and nonpoint sources of $\mathrm{N}$ pollution may result in the continued biomass accumulation in these systems. Additionally, the ability of Lake Erie bloom community to use urea as a N source, with the near 100-fold increase of urea use as a nitrogen fertilizer (Glibert et al., 2006), supports the ecological importance of the linkages between urea fertilization and transport to downstream waters, and clear need to better characterize these processes in future work 
Acknowledgements. We thank the captain and crew of the C.C.G.S. Limnos as well as Katherine Perri for assistance in the field and collecting the AOA measurements. We also thank Professor William Taylor and two anonymous reviewers for comments that greatly improved the paper. This project was supported by grants from the National Science Foundation (IOS 0841918, DEB - 1240870 and CBET- 1230543), access of ship time through Environment Canada and the Kenneth \& Blaire Mossman Professorship to the University of Tennessee. 


\section{List of References}

Ashworth, W. The late, Great Lakes: an environmental history. Detroit, MI:Wayne State University Press; 1986.

Auinger, B. M., Pfandl, K., Boenigk, J. 2008. Improved methodology for identification of protists and microalgae from plankton samples preserved in Lugol's iodine solution: combining microscopic analysis with single-cell PCR. Appl. Environ. Microbiol. 74, 2505-10.

Berg, G. M., Jorgensen, N. O. G. 2006. Purine and pyrimidine metabolism by estuarine bacteria. Aquat. Microb. Ecol. 42, 215-26.

Bogard, M., donald, D. B., Finlay, K., Leavitt, P. R. 2012. Distribution and regulation of urea in lakes of central North America. Freshw. Biol. 57, 1277-92.

Boyer, G. L. 2007. The occurrence of cyanobacterial toxins in New York lakes: Lessons for the MERHAB-lower Great Lakes program. Lake Reservoir Management 23, 153-60.

Brittain, S. M., Wang, J., Babcock-Jackson, L., Carmichael, W. W., Rinehart, K. L., Culver, D. A. 2000. Isolation and characterization of microcystins, cyclic heptapeptide hepatotoxins from a Lake Erie strain of Microcystis aeruginosa. J Gt Lakes Res 26, 241-9.

Carmichael, W. W., An, J. 1999. Using an enzyme linked immunosorbent assay (ELISA) and a protein phosphatase inhibition assay (PPIA) for the detection of microcystins and nodularins. Nat. Toxins 7 , 377-85.

Chaffin, J. D., Bridgeman, T. B. 2014. Organic and inorganic nitrogen utilization by nitrogen-stressed cyanobacteria during bloom conditions. J. Appl. Phycol. 26, 299-309.

Chaffin, J. D., Bridgeman, T. B., Bade, D. L. 2013. Nitrogen contrains the growth of late summer cyanobacterial blooms in Lake Erie. Adv. Microbiol. 3, 16-26.

Charlton, M. N. 1980. Oxygen depletion in Lake Erie: has there been any change. Can J Fish Aquat Sci 37, 72-81.

Chorus, I., Bartram, J. Toxic cyanobacteria in water; a quide to their public health consequences, monitoring and management. London:E \& FN Spon; 1999.

Collier, J. L., Baker, K. M., Bell, S. L. 2009. Diversity of urea-degrading microorganisms in open-ocean and estuarine planktonic communities. Environ. Microbiol. 11, 3118-31.

Conroy, J. D., Kane, D. D., Dolan, D. M., Edwards, W. J., Charlton, M. N., Culver, D. A. 2005. Temporal Trends in Lake Erie Plankton Biomass: Roles of External Phosphorus Loading and Dreissenid Mussels. J. Great Lakes Res. 31, 89-110.

Davis, T. W., Bullerjahn, G. S., Tuttle, T., McKay, R. M., Watson, S. B. 2015. Effects of increasing nitrogen and phosphorus concentrations on phytoplankton community growth and toxicity during Planktothrix blooms in Sandusky Bay, Lake Erie. Environ. Sci. Technol. 49, 7197-207.

Davis, T. W., Harke, M. J., Marcoval, M. A., Goleski, J., Orano-Dawson, C., Berry, D. L. et al. 2010. Effects of nitrogenous compounds and phosphorus on the growth of toxic and non-toxic strains of Microcystis during cyanobacterial blooms. Aquat. Microb. Ecol. 61, 149-62.

DeBruyn, J. M., Leigh-Bell, J. A., McKay, R. M. L., Bourbonniere, R. A., Wilhelm, S. W. 2004. Microbial distributions and the impact of phosphorus on bacterial activity in Lake Erie. J. Great Lakes Res. 30, 166-83.

Donald, D. B., Bogard, M. J., Kinlay, K., Leavitt, P. R. 2011. Comparative effects of urea, ammonium, and nitrate on phytoplankton abundance, community composition, and toxicity in hypereutrophic freshwaters. Limnol. Oceanogr. 56, 2161-75.

Finlay, K., Patoine, A., Donald, D. B., Bogard, M., Leavitt, P. R. 2010. Experimental evidence that pollution with urea can degrade water quality in phosphorus-rich lakes of the northern Great Plains. Limnol. Oceanogr. 55, 1213-30.

Frangeul, L., Quillardet, P., Castets, A. M., Humbert, J. F., Matthijs, H. C., Cortez, D. et al. 2008. Highly plastic genome of Microcystis aeruginosa PCC7806, a ubiquitous toxic freshwater cyanobacterium. BMC Genomics 9, doi:10.1186/471-2164-9-274. 
Glibert, P. M., Harrison, J., Heil, C., Seitzinger, S. 2006. Escalating worldwide use of urea - a global change contributing to coastal eutrophication. Biogeochemistry 77, 441-63.

Glibert, P. M., Maranger, R., Sobota, D. J., Bouwman, L. 2014. The Haber Bosch-harmful algal bloom (HB-HAB) link. Environmental Research Letters 9, 105001.

Guillard, R. L., Sieracki, M. S. Counting Cells in Cultures with the Light Microscope. Algae Culturing Techniques. 2005. p. 239-52.

Han, X., Zhu, G., Xu, H., Wilhelm, S. W., Qin, B., Li, Z. 2014. Source analysis of urea-N in Lake Taihu during the summer. Environmental Sciences 35, 2547-56.

Hare, C. E., DiTullio, G. R., Trick, C. G., Wilhelm, S. W., Bruland, K. W., Rue, E. L. et al. 2005. Phytoplankton community structure changes following simulated upwelled iron inputs in the Peru Upwelling region. Aquat. Microb. Ecol. 38, 269-82.

Ho, J. C., Michalak, A. M. 2015. Challenges in tracking harmful algal blooms: a synthesis of evidence from Lake Erie. J Great Lakes Res. 41, 317-325.

Huang, W. M., Bi, Y. H., Hu, Z. Y. 2014. Effects of fertilizer-urea on growth, photosynthetic activity and microcystins production of Microcystis aeruginosa isolated from Dianchi Lake. Bull Environ Contam Toxicol 92, 514-9.

Juan, Y. H., Chen, Z. H., Chen, L. J., Wu, Z. J., Wang, R., Sun, W. T. et al. 2010. Kinetic and thermodynamic behaviors of soil urease as affected by urease inhibitors. Revista de la Ciencia del Suelo y Nutricion Vegetal 10, 1-11.

Kaneko, T., Nakajima, N., Okamoto, S., Suzuki, I., Tanabe, Y., Tamaoki, M. et al. 2007. Complete genomic structure of the bloom-forming toxic cyanobacterium Microcystis aeruginosa NIES-843. DNA Research 14, 247-56.

Kring, S. A., Figary, S. E., Boyer, G. L., Watson, S. B., Twiss, M. R. 2014. Rapid in situ measures of phytoplankton communities using the bbe fluoroProbe: evaluation of spectral calibration, instrument intercompatibility and performance range. Can. J. Fish. Aquat. Sci. 71, 1087-95.

Mackerras, A. H., Smith, G. D. 1986. Urease activity of the cyanobacterium Anabaena cylindrica. J. General Microbiol. 132, 2749 - 52.

McGinn, P. J., D., P. G., Maleszka, R., Badger, M. R. 2003. Inorganic carbon limitation and light control the expression of transcripts related to the $\mathrm{CO}_{2}$-concentrating mechanism in the cyanobacterium Synechocystis sp. strain PCC6803. Plant Physiol. 132, 218-29.

McLachlan, J., Gorham, P. R. 1962. Effects of pH and nutrogen sources on Microcystis aeruginosa Kutz. Can. J. Microbiol. 8, 1-11.

Neilan, B. A., Pearson, L. A., Muenchhoff, J., Moffitt, M. C., Dittman, E. 2013. Environmental conditions that influence toxin biosynthesis in cyanobacteria. Environ. Microbiol. 15, 1239-53.

NLET, 1994. Manual of Analytical Methods: Major Ion and Nutrients, in: Canada E (Ed.), Burlington, ON.

Oliver, R. L., Hamilton, D. P., Brookes, J. D., Ganf, G. G. Physiology, Blooms and Prediction of Planktonic Cyanobacteria. In: Whitton BA editor. Ecology of Cyanobacteria II: Their Diversity in Space and Time. Springer Science; 2012. p. 115 - 87.

Penn, K., Wang, J., Fernando, S. C., Thompson, J. R. 2014. Secondary metabolite gene expression and interplay of bacterial functions in a tropical freshwater cyanobacterial bloom. ISME J. 8, 1866-78.

Qin, B., Zhu, G., Gao, G., Zhang, Y., Li, W., Paerl, H. et al. 2010. A drinking water crisis in Lake Taihu, China: linkage to climatic variability and lake management. Environmental Management 45, 105-12.

Revilla, M., Alexander, J., Glibert, P. M. 2005. Urea analysis in coastal waters: comparison of enzymatic and direct methods. Limnol. Oceanogr. -Methods 3, 290-9.

Rinta-Kanto, J. M., Konopka, E. A., DeBruyn, J. M., Bourbonniere, R. A., Boyer, G. L., Wilhelm, S. W. 2009a. Lake Erie Microcystis: relationship between microcystin production, dynamics of genotypes and environmental parameters in a large lake. Harmful Algae 8, 665-73. 
Rinta-Kanto, J. M., Ouellette, A. J. A., Boyer, G. L., Twiss, M. R., Bridgeman, T. B., Wilhelm, S. W. 2005. Quantification of toxic Microcystis spp. during the 2003 and 2004 blooms in western Lake Erie using quantitative real-time PCR. Environ. Sci. Technol. 39, 4198-205.

Rinta-Kanto, J. M., Saxton, M. A., DeBruyn, J. M., Smith, J. L., Marvin, C. H., Krieger, K. A. et al. 2009b. The diversity and distribution of toxigenic Microcystis spp. in present day and archived pelagic and sediment samples from Lake Erie. Harmful Algae 8, 385-94.

Saxton, M. A., Arnold, R. J., Bourbonniere, R. A., McKay, R. M. L., Wilhelm, S. W. 2012. Plasticity of total and intracellular phosphorus quotas in Microcystis aeruginosa cultures and Lake Erie algal assemblages Frontiers in Microbiol. 3, 10.3389/fmicb.2012.0000

Šejnohová, L., Maršálek, B. Microcystis. In: Whitton BA editor. Ecology of Cyanobacteria II: Their Diversity in Space and Time. Springer Science; 2012. p. 195-277.

Solomon, C. M., 2006. Regulation of estuarine phytoplankton and bacterial urea uptake and urease activity by environmental factors. University of Maryland, College Park, MD.

Solomon, C. M., Alexander, J. A., Glibert, P. M. 2007. Measuring urease activity in aquatic environmental samples. Limnol. Oceanogr.-Methods 5, 280-8.

Solomon, C. M., Collier, J. L., Berg, G. M., Glibert, P. M. 2010. Role of urea in microbial metabolism in aquatic systems: a biochemical and molecular review. Aquat. Microb. Ecol. 59, 67-88.

Steffen, M. M., Belisle, B. S., Watson, S. B., Bourbonniere, R. A., Boyer, G. L., Wilhelm, S. W. 2015. Metatranscriptomic evidence for co-occurring top-down and bottom-up controls on toxic cyanobacterial communities. Appl. Environ. Microbiol. 81, 3268-75.

Steffen, M. M., Belisle, B. S., Watson, S. B., Boyer, G. L., Wilhelm, S. W. 2014a. Review: Status, causes and consequences of cyanobacterial blooms in Lake Erie. J. Great Lakes Res. 40, 215-25.

Steffen, M. M., Dearth, S. P., Dill, B. D., Li, Z., Larsen, K. M., Campagna, S. R. et al. 2014b. Nutrients drive transcriptional changes that maintain metabolic homeostasis but alter genomic architecture in Microcystis. ISME J. 8, 2080-92.

USDA-ERS, 2013. U.S. consumption of selected nitrogen materials, 1960-2011. http://www.ers.usda.gov/data-products/fertilizer-use-and-price.aspx accessed Feb 8, 2016

Wehr, J. D., Sheath, R. G. Freshwater Algae of North Ameraica: Ecology and Classification.Elsevier Inc.; 2003.

Welschmeyer, N. A. 1994. Fluorometric analysis of chlorophyll a in the presence of chlorophyll b and pheopigments. Limnol. Oceanogr. 39, 1985-92.

Wiegner, T. N., Seitzinger, S. P., GLibert, P. M., Bronk, D. A. 2006. Bioavailability of dissolved organic nitrogen and carbon from nine rivers in the eastern United States. Aquat. Microb. Ecol. 43, 277-87.

Wilhelm, S. W., DeBruyn, J. M., Gillor, O., Twiss, M. R., Livingston, K., Bourbonniere, R. A. et al. 2003. Effect of phosphorus amendments on present day plankton communitites in pelagic Lake Erie. Aquat. Microb. Ecol. 32, 275-85.

Xu, H., Paerl, H. W., Qin, B., Zhu, G. H., Gao, G. 2010. Nitrogen and phosphorus inputs control phytoplankton growth in eutrophic Lake Taihu, China. Limnol. Oceanogr. 55, 420-32.

Zingone, A., Enevoldsen, H. O. 2000. The diversity of harmful algal blooms: a challenge for science and management. Ocean \& Coastal Management 43, 725-48. 


\section{FIGURE LEGENDS}

Figure 1: Lake Erie map of environmental sampling stations visited during the August 2012, May 2013, and July 2013 sampling cruises, aboard the CCGS Limnos. Stations where microcosm assays were performed (885 and 973) are shown in bold font.

Figure 2: Relationship between chlorophyll $a$ concentrations and urease activity for August 2012 (A), May 2013 (B) and July 2013 (C). Error bars are the range of duplicate measurements for each sample. Where not shown, error bars are within the size of the symbol.

Figure 3. Volcano plots of Spearman's statistical relationships between A) urea concentrations, B) urease activity and C) urea turnover rate (h) for stations sampled in Lake Erie. Plots demonstrate statistical significance $(\mathrm{p}<0.05)$ of relationships on the Y-axis and the strength of the relationship (as Spearman's rho) on the $\mathrm{X}$-axis. Floating $\mathrm{X}$-axis denotes $\mathrm{p}=0.05$ (points above this area considered statistically significant). Data are reported in ESM Table S2.

Figure 4. Principle component analysis of stations from all three cruises. $\triangle$ - Aug 2012; $\nabla$ - May 2013; July 2013. Stations generally cluster by sampling date - outliers at stations 741, 1326 and 1163 are labeled.

Figure 5. Biomass estimates for microcosms at stations 973 (A, C, E) and 885 (B, D, F) for August 2012 (A, B), May 2013 (C, D) and July 2013 (E, F). Controls (open bars) are compared to $+1 \mu \mathrm{M}-\mathrm{P}$ (grey) or $+180 \mu \mathrm{M}$ $\mathrm{N}$ (black) as ammonium, nitrate or urea. Statistically similar treatments $(\mathrm{n}=3$ biological replicates, \pm SD) are denoted with similar letters above bars. 
Table 1: Data for surface waters from cruises $(Z=1 \mathrm{~m})$. ND indicates measurements were not determined. For microcystin concentrations, samples outside standards are reported as < or > limits. The percent chlorophyll assigned to cyanobacteria are for PC-rich cells only (see methods). Urea concentrations are presented both as those that were directly measured (mass per volume) and as the conversion to molar concentration.

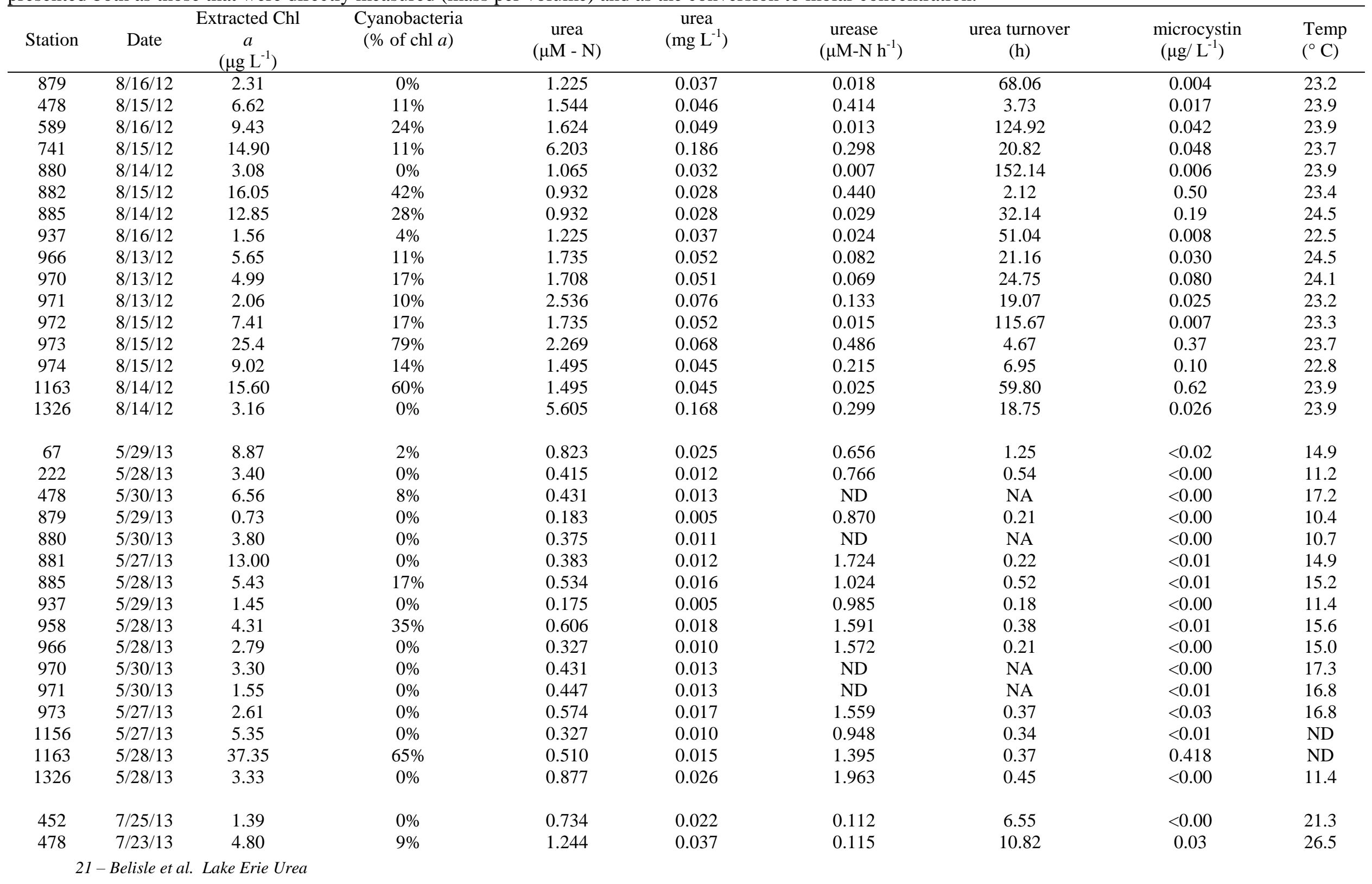




\begin{tabular}{|c|c|c|c|c|c|c|c|c|c|}
\hline 741 & $7 / 24 / 13$ & 18.00 & $11 \%$ & 3.333 & 0.100 & 0.494 & 6.75 & $<0.03$ & 26.9 \\
\hline 880 & $7 / 25 / 13$ & 1.44 & $0 \%$ & 1.069 & 0.032 & 0.149 & 7.17 & $<0.00$ & 23.6 \\
\hline 882 & $7 / 24 / 13$ & 6.54 & $49 \%$ & 1.427 & 0.043 & 0.106 & 13.46 & 0.13 & 25.2 \\
\hline 885 & $7 / 23 / 13$ & 21.00 & $55 \%$ & 0.710 & 0.021 & 0.225 & 3.16 & 0.235 & 25.7 \\
\hline 937 & $7 / 22 / 13$ & 4.46 & $64 \%$ & 1.148 & 0.034 & 0.054 & 21.26 & $<0.00$ & 19.8 \\
\hline 958 & $7 / 24 / 13$ & 1.06 & $63 \%$ & 1.364 & 0.041 & 0.104 & 13.12 & 0.04 & 25.5 \\
\hline 970 & $7 / 23 / 13$ & 3.47 & $6 \%$ & 0.893 & 0.027 & 0.049 & 18.22 & 0.03 & 25.5 \\
\hline 971 & $7 / 23 / 13$ & 4.24 & $16 \%$ & 1.643 & 0.049 & 0.173 & 9.50 & $<0.00$ & 25.9 \\
\hline 973 & $7 / 24 / 13$ & 3.44 & $21 \%$ & 2.113 & 0.063 & 0.157 & 13.46 & 0.07 & 25.2 \\
\hline 1163 & $7 / 23 / 13$ & 72.45 & $28 \%$ & 2.041 & 0.068 & 0.200 & 10.21 & 0.11 & 26.4 \\
\hline 1326 & $7 / 24 / 13$ & 3.04 & $0 \%$ & 1.388 & 0.046 & 0.187 & 7.42 & $<0.00$ & 23.6 \\
\hline
\end{tabular}


Figures 1-5

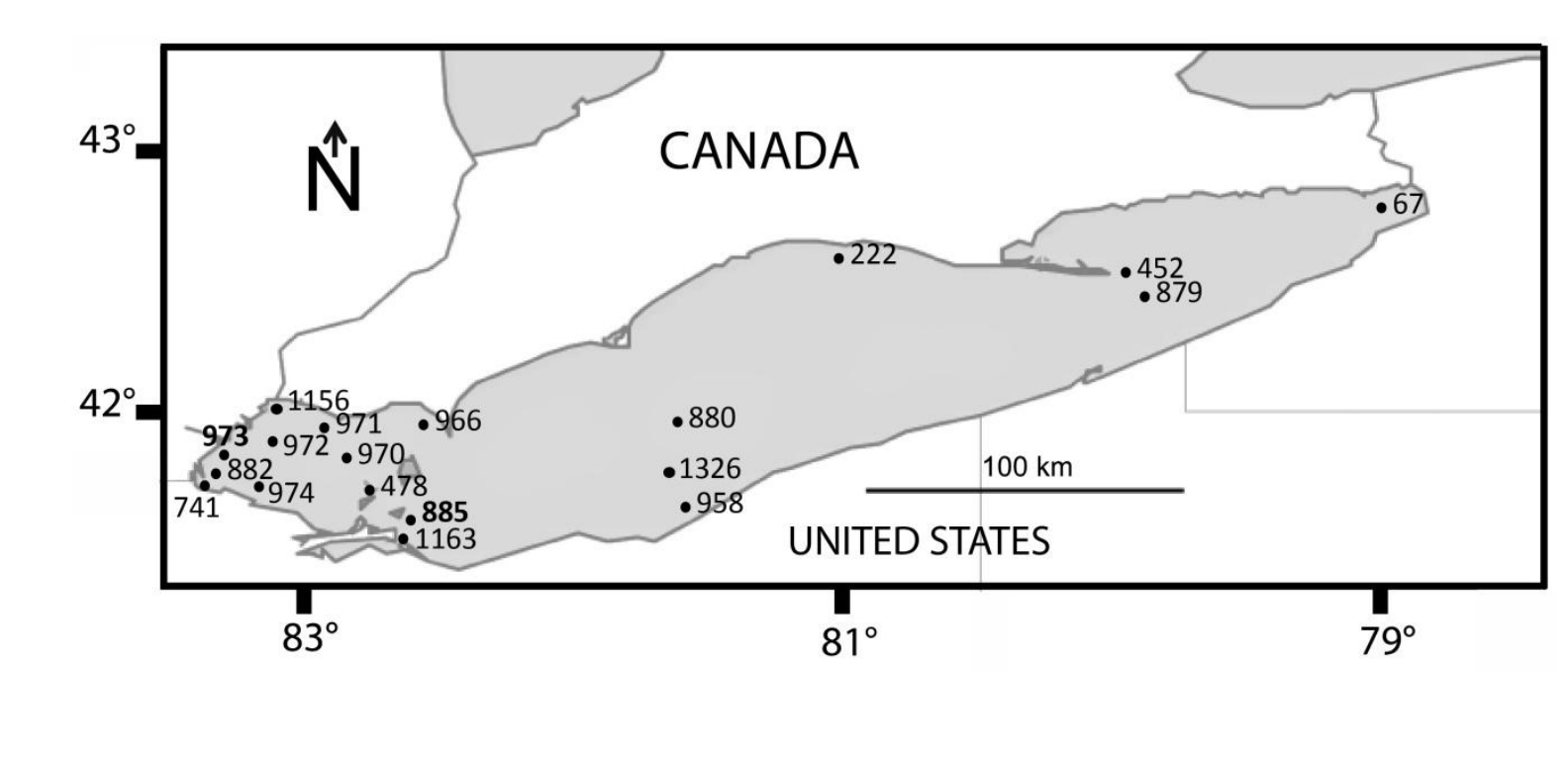

Figures 1-5

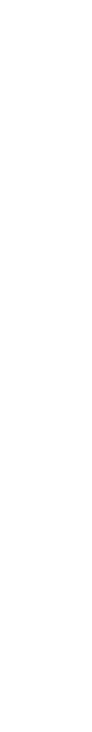

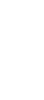
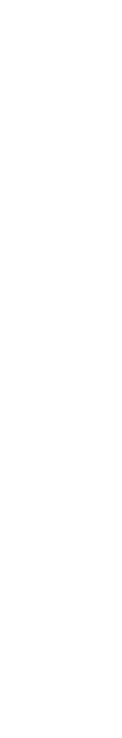

.
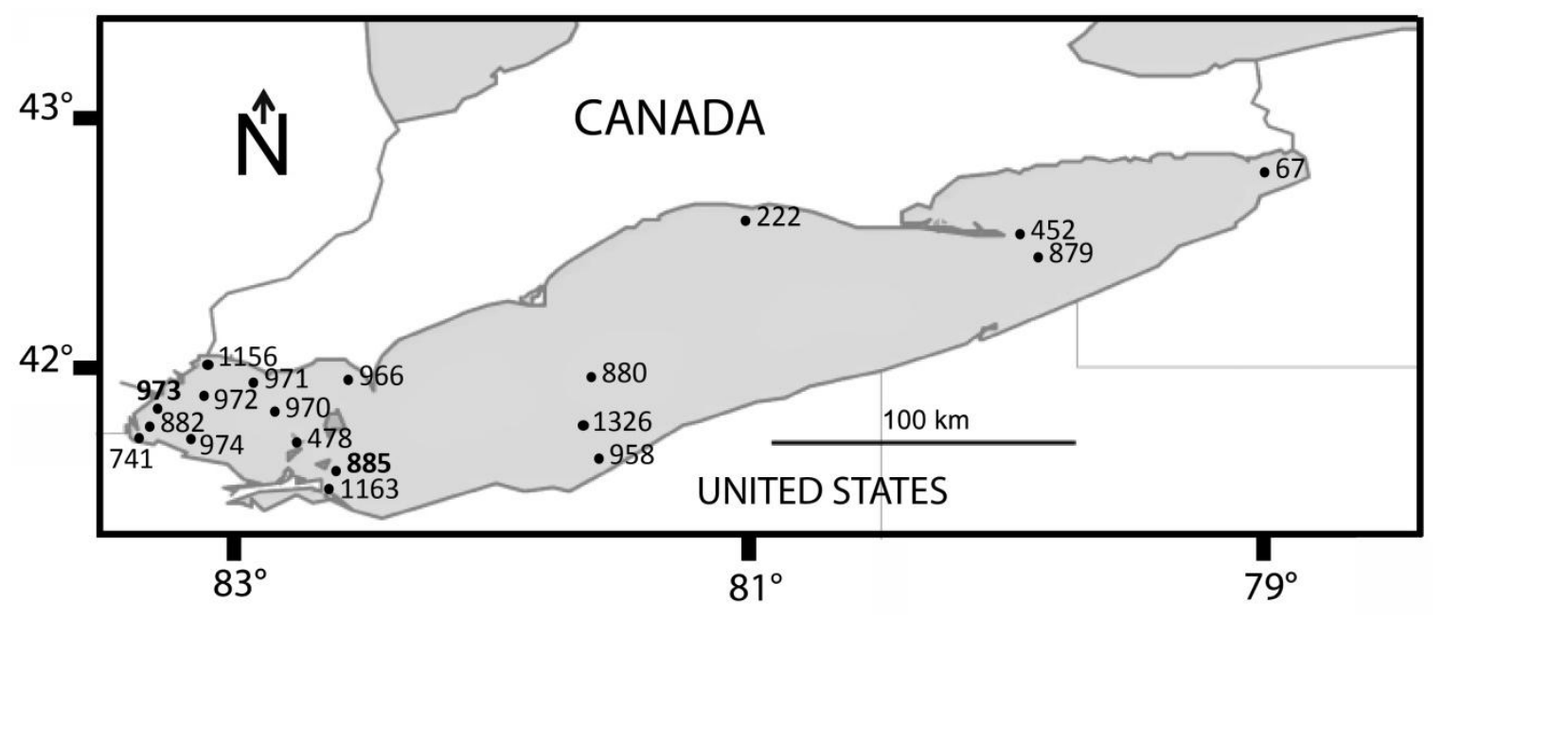
Figure 2.
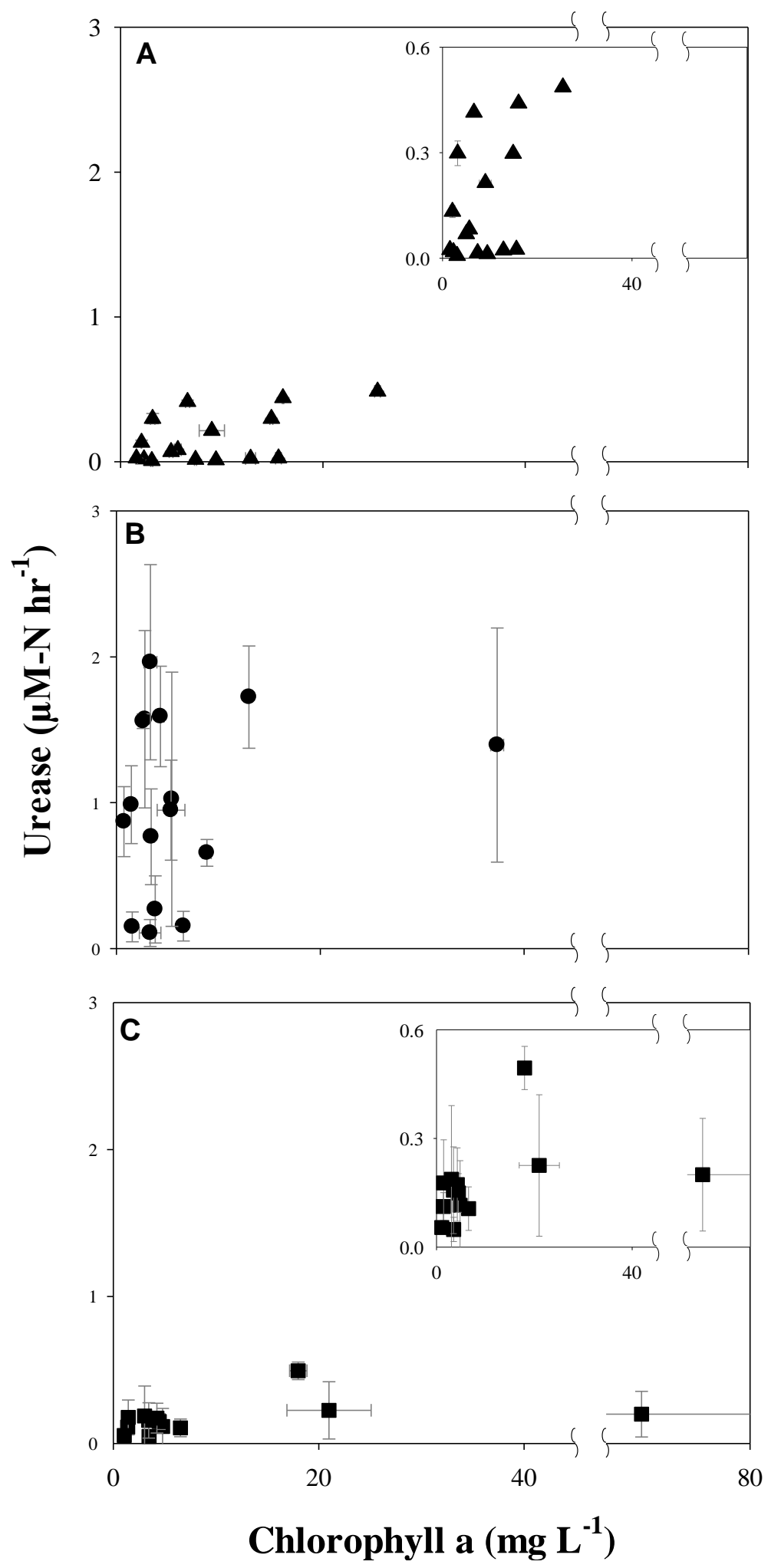
Figure 3.
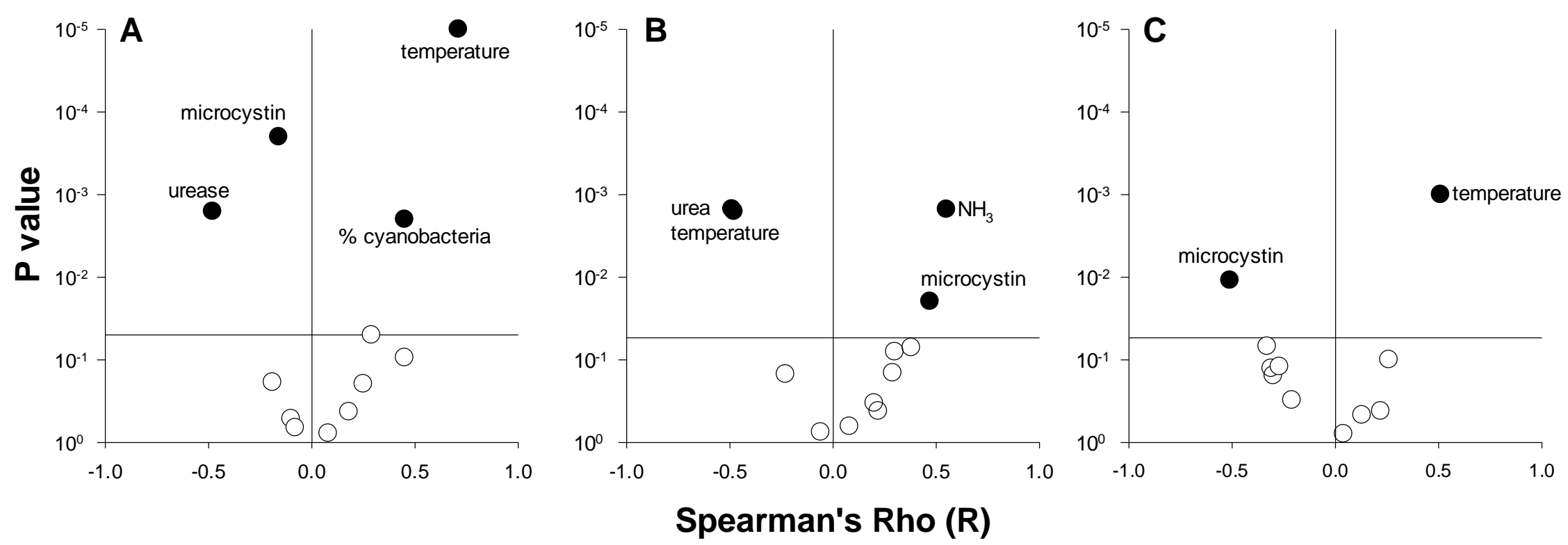
Figure 4.

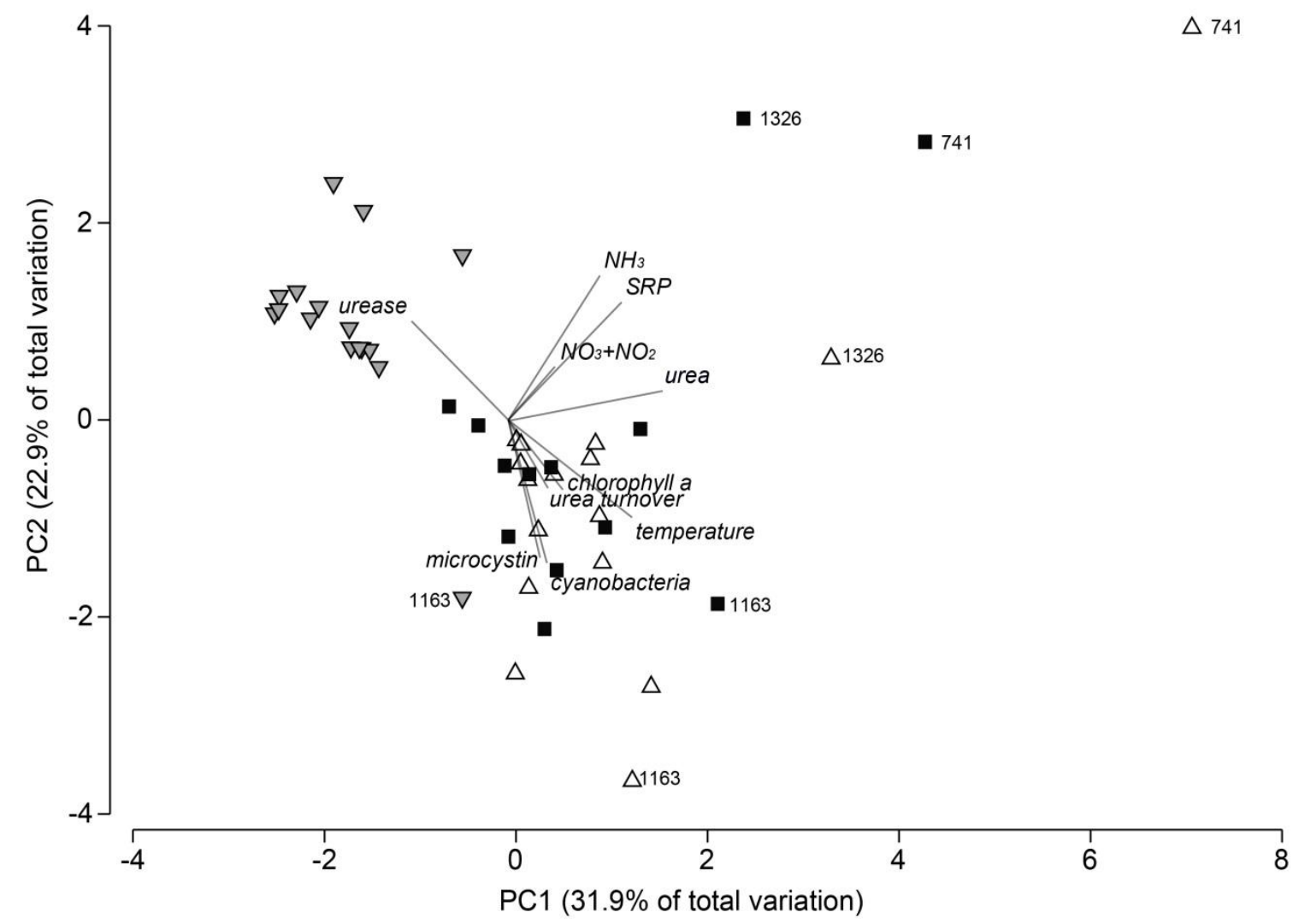


Figure 5.

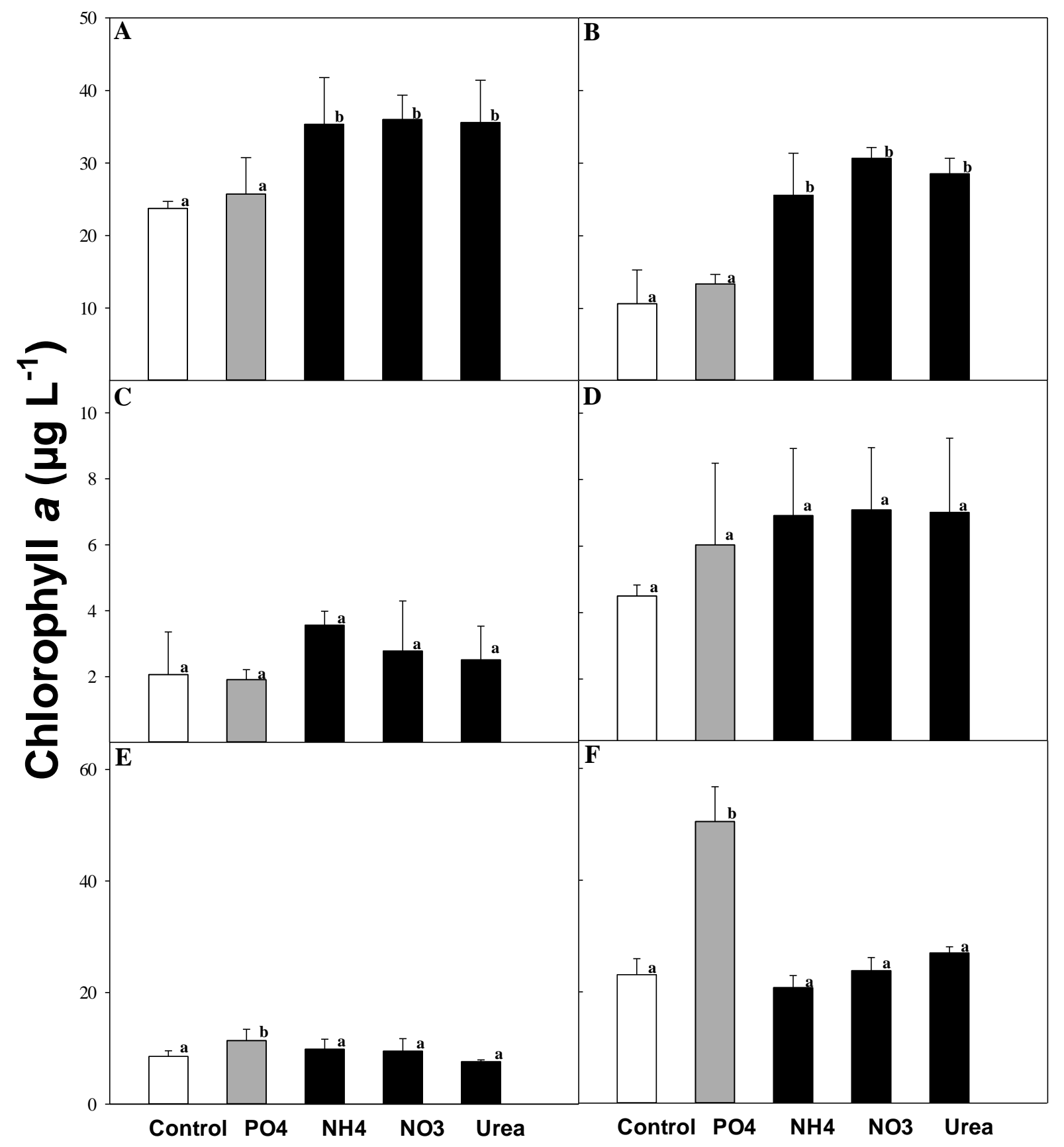

